\title{
Study of In-Vivo Effects Caused by Metabolites (1,2,4-Trizole Alanine) of Steroid-Inhibitor Fungicide on Aquatic Life (Fish)
}

\section{Pallavi Srivastava and Ajay Singh*}

Department of Zoology, Natural Product Laboratory, D.D.U.University Gorakhpur, India

\begin{abstract}
The fungicide PCZ (propiconazole) is widely used in agriculture especially in Asian contries as India, China ect. for the production of vegetable crops. Because of its physical and chemical properties, the small concentration of PCZ in water bodies "habitate of aquatic flora and fauna" make it sever in conditions for survivle. On the basis of analysis of all data in present study, the central theory that environmentally relevant conentrations of PCZ affect biochemical parameters in fish. The conclusion also hold that the theories such as metabolites of trizole convert the enzyme activities also. The $L C$ values $\left(L_{50}\right)$ estimate on different life stages of fish that was dose as well as time dependent. The exposure of sub-lethal concentration of PCZ in vivo assessment studied after $24 \mathrm{~h}$ and $72 \mathrm{~h}$ during exposure with $40 \%$ and $80 \%$ of $\mathrm{LC}_{50}(0.56 \mathrm{mg} / \mathrm{l}, 1.12 \mathrm{mg} / \mathrm{l}$ for fingerlings respectively) \& $(1.11 \mathrm{mg} / \mathrm{l}, 2.23 \mathrm{mg} / \mathrm{l}$ for adults respectively). Protein, Amino acids, Glycogen, Nucleic acids and enzyme succinic dehydrogenase decreased in liver and muscles, but lactic dehydrogenase levels, Protease, GOT and GPT increased in the both tissues. The study shows that PCZ have potential to damage aquatic ecosystem. Therefore, we can say that this fungicide should avoid in near water bodies.
\end{abstract}

Keywords: PCZ (Propiconazole); In Vivo; Flora and Fauna; Biochemical parameters

\section{Introduction}

Trizole containing fungicides are used as antifungal in agriculture for controling pest and also for increasing food crops [1,2]. Propiconazole induced severe effects on hepatic nuclear receptor activation, hepatic hypertrophy, cytochrome P450s induction, cell proliferation, all-trans retinoic acid level and on serum cholesterol levels [3-5] in organisms.

Propiconazole is a number of DMI(demethylation inhiitors) group with rapid acropetal systemicity. It acts on the pathogen inside the plant to stop disease development by interfering with sterol biosynthesis in fungal cell membrane.

The foliar systemic fungicides propiconazole (PCZ), had chemical formula 1-(2-(2, 4-dichlorophenyl)-4-propyl-1, 3-dioxolan-2ylmethyl)-1H-1,2,4-trizole. They have a shorter half-life and lower bioaccumulation but announced effects on the aquatic ecosystems may arise from spray drift or surface run-off [6]. They have reported to undergo transformation of secondary metabolites in terrestrial mammals [7]. Series of study shows that the PCZ altered the metabolic pathways, cell signaling, cell growth pathways, cell cycle genes and other transcriptional factors [8,9]. Nevertheless, the toxic effects of PCZ on fishes have not adequately researched.

The aim of present study is to evaluate the toxicity and the effect of sub-lethal doses of PCZ to analyze the biochemical, physiological and enzymatic responses is fresh-water fish Clarius batracus, is an important fish of Indian capture fishery.

\section{Materials and Methods}

\section{Chemical}

Propiconazole have local name Tilt is a systemic fungicide purchased from Syngenta Ltd. from India, a technical grade pesticide.

\section{Experimented animals}

The fresh-water fish Clarius batracus (total average size 12-17 cm and average weight $35-50 \mathrm{~g}$ ) for adult and for fingerlings (total average size 6-8 cm and average weight 9-12 g) brought from local fresh-water pond. They were stored in laboratory tank containing 100 liters of dechlorinated tap water and acclimatized to the laboratory conditions for $72 \mathrm{~h}$.

\section{Experimental design}

Toxicity test perform by the method of Singh and Agarwal [10]. Five fishes kept in glass aquaria containing $10 \mathrm{~L}$ de-chlorinated tap water. Fish exposed for $24 \mathrm{~h}$ to $96 \mathrm{~h}$ to four different concentrations of pesticides in laboratory. Control fish kept in similar conditions without any treatment. Each group of fish replicated three times. Mortality recorded after every $24 \mathrm{~h}$. Dead animals removed to prevent the decomposition of body in experimental aquarium. The effective doses (LC values, upper and lower confidence limits, slope value, and heterogeneity) calculated by probit log method. Product moment corelation co-efficient was applied in between exposure time and lethal concentration (Sokal and Rohef) [11].

\section{Tissue preparation}

Fishes exposed to $40 \%$ and $80 \%$ of $24 \mathrm{~h} \mathrm{LC}_{50}$ doses $(1.11 \mathrm{mg} / \mathrm{l}, 2.23$ $\mathrm{mg} / \mathrm{l}$ respectively). Experiment conducted from $24 \mathrm{~h}$ to $72 \mathrm{~h}$. After completion of treatment the test, fishes were removed and washed with water, killed by severe blow on head, and operated their liver and muscles quickly dissected out in ice tray and used for biochemical and enzymatic analyses. Control fishes kept in similar condition without any treatment. Each experiment replicated at least 6 times and values expressed as mean \pm SE of six replicates. Following parameters tested by different methods.

*Corresponding author: Ajay Singh, Department of Zoology, Natural Product Laboratory, D.D.U.University Gorakhpur, India, E-mail: 5september1984@gmail.com

Received January 17, 2013; Accepted February 22, 2013; Published March 02, 2013

Citation: Srivastava P, Singh A (2013) Study of In-Vivo Effects Caused by Metabolites (1,2,4-Trizole Alanine) of Steroid-Inhibitor Fungicide on Aquatic Life (Fish). J Aquac Res Development 4: 183 doi:10.4172/2155-9546.1000183

Copyright: (c) 2013 Srivastava P, et al. This is an open-access article distributed under the terms of the Creative Commons Attribution License, which permits unrestricted use, distribution, and reproduction in any medium, provided the original author and source are credited. 
Citation: Srivastava P, Singh A (2013) Study of In-Vivo Effects Caused by Metabolites (1,2,4-Trizole Alanine) of Steroid-Inhibitor Fungicide on Aquatic Life (Fish). J Aquac Res Development 4: 183 doi:10.4172/2155-9546.1000183

Protein level estimated according to the method of Lowery et al. [12] using bovine serum albumin as standard. Estimation of total free amino acids made according to the method of Spices [13]. Estimation of DNA and RNA performed by method of Schneider [14] using diphenylamine and orcinol reagents respectively. Glycogen estimated by Anthrone method of Van Der Vies [15].

Lactic dehydrogenase, the method of Anon [16]. Succinic dehydrogenase, the method of Arrigoni and Singer [17]. Protease, method of Moore and Stein [18]. GOT and GPT, method of Reitman and Frankel [19]. Two ways ANOVA performed between control and tested group. The significant level was 0.05 .

\section{Results}

Study shows, PCZ cause announce alteration in behavior and metabolic anomalies such as level of glycogen, protein, amino acids, nucleic acids and enzymes like Lactic dehydrogenase, Succinic dehydrogenase, Protease, GOT and GPT (Glutamic oxalic trasaminase and Glutamic pyruvate transaminase). The toxicity data is presented in Table 1 and biochemical and enzymatic values of $40 \% \& 80 \%$ of $\mathrm{LC}_{50}$ $(0.56 \mathrm{mg} / \mathrm{l}, 1.12 \mathrm{mg} / \mathrm{l})$ presented in Tables 2 and 3 .

After exposures of $40 \%$ of $\mathrm{LC}_{50},(0.56 \mathrm{mg} / \mathrm{l})$ the level of protein is depleted $85 \%$ in muscles tissue, $80 \%$ in liver at $24 \mathrm{~h}, 68 \%$ in muscle tissue, and $60 \%$ in liver at $72 \mathrm{~h}$. While amino-acids level is increases $118 \%$ in muscles and $115 \%$ in liver at $24 \mathrm{~h}$ and $125 \%$ in muscles and $120 \%$ in liver at $72 \mathrm{~h}$. Glycogen level become reduces $78 \%$ and $65 \%$ in muscle and liver respectively at $24 \mathrm{~h}$, it progressively decreases $59 \%$ and $62 \%$ in muscle and liver respectively at $72 \mathrm{~h}$. The trend of decrement also observed in DNA, RNA and level of SDH activity. It becomes $77 \%$, $75 \%, 76 \%, 73 \%, 65 \%$ and $63 \%$ in muscles and liver respectively at $24 \mathrm{~h}$ and $62 \%, 60 \%, 65 \%, 62 \%, 66 \%$ and $58 \%$ in muscles and liver respectively at $72 \mathrm{~h}$. The enzymetic level increase at $24 \mathrm{~h}$ and $72 \mathrm{~h}$ in both tissues. Protease becomes $115 \%$ and $130 \%$ in muscle and liver at $24 \mathrm{~h}$ and $125 \%$ and $138 \%$ in muscles and liver at $72 \mathrm{~h}$. While Lactic dehydrogenase level is increases $112 \%$ in muscles and $113 \%$ in liver at $24 \mathrm{~h}$ and $116 \%$ in muscles and $120 \%$ in liver at $72 \mathrm{~h}$. The transaminase reactivity also shows increase level in muscle and liver. GOT becomes $120 \%$ and $128 \%$ in muscle and liver at $24 \mathrm{~h}$ and $124 \%$ and $135 \%$ in muscles and liver at $72 \mathrm{~h}$. GPT also increase $115 \%$ in muscles and $124 \%$ in liver at $24 \mathrm{~h}$ and $119 \%$ in muscles and $130 \%$ in liver at $72 \mathrm{~h}$.

After exposures of $80 \%$ of $\mathrm{LC}_{50},(1.12 \mathrm{mg} / \mathrm{l})$ the trend is similar as level of protein is depleted $78 \%$ in muscles tissue and $71 \%$ in liver at 24 $\mathrm{h}$ and $62 \%$ in muscle tissue and $55 \%$ in liver at $72 \mathrm{~h}$. While amino-acids level is increases $123 \%$ in muscles and $120 \%$ in liver at $24 \mathrm{~h}$ and $135 \%$ in muscles and $140 \%$ in liver at $72 \mathrm{~h}$. Glycogen level become reduces $68 \%$ and $52 \%$ in muscle and liver respectively at $24 \mathrm{~h}$, it progressively decreases $55 \%$ and $49 \%$ in muscle and liver respectively at $72 \mathrm{~h}$. The trend of decrement also observed in DNA, RNA and level of SDH (Succinic dehydrogenase) activity. It becomes $70 \%, 68 \%, 72 \%, 66 \%, 60 \%$ and $57 \%$ in muscles and liver respectively at $24 \mathrm{~h}$ and 58\%, 56\%, 59\%, 57\%, 55\% and $52 \%$ in muscles and liver respectively at $72 \mathrm{~h}$. The enzymetic level increase at $24 \mathrm{~h}$ and $72 \mathrm{~h}$ in both tissues. Protease becomes $120 \%$ and $136 \%$ in muscle and liver at $24 \mathrm{~h}$ and $132 \%$ and $143 \%$ in muscles and liver at $72 \mathrm{~h}$. While LDH (Lactic dehydrogenase) level is increases $118 \%$ in muscles and $120 \%$ in liver at $24 \mathrm{~h}$ and $125 \%$ in muscles and $130 \%$ in

\begin{tabular}{|c|c|c|c|c|}
\hline Exposure periods & Effective doses (mg/L) & Slope & Effective doses (mg/L) & Slope \\
\hline & Fingerlings & & Adult Fish & \\
\hline & $L_{10}=0.84 \quad(0.26-1.06)$ & & $\mathrm{LC}_{10}=2.44(2.14-2.55)$ & \\
\hline \multirow[t]{3}{*}{$24 \mathrm{~h}$} & $\mathrm{LC}_{50}=1.40(1.19-1.74)$ & $5.75 \pm 2.06$ & $\mathrm{LC}_{50}=2.79(2.68-3.01)$ & $21.84 \pm 6.13$ \\
\hline & $\mathrm{LC}_{90}=2.34(1.83-2.69)$ & & $\mathrm{LC}_{90}=3.19(2.97-3.99)$ & \\
\hline & $\mathrm{LC}_{10}=0.80(0.32-1.01)$ & & $\mathrm{LC}_{10}=2.16(1.68-2.33)$ & \\
\hline \multirow[t]{3}{*}{$48 \mathrm{~h}$} & $\mathrm{LC}_{50}=1.28(1.05-1.46)$ & $6.35 \pm 2.08$ & $\mathrm{LC}_{50}=2.59(2.44-2.74)$ & $16.51 \pm 4.84$ \\
\hline & $\mathrm{LC}_{90}=2.04(1.69-4.39)$ & & $\mathrm{LC}_{90}=3.09(2.87-3.98)$ & \\
\hline & $\mathrm{LC}_{10}=0.72(0.29-0.92)$ & & $\mathrm{LC}_{10}=2.08(1.64-2.24)$ & \\
\hline \multirow[t]{3}{*}{$72 \mathrm{~h}$} & $\mathrm{LC}_{50}=1.10(0.81-1.24)$ & $7.03 \pm 2.17$ & $\mathrm{LC}_{50}=2.39(2.22-2.50)$ & $20.71 \pm 5.74$ \\
\hline & $\mathrm{LC}_{90}=1.68(1.46-2.62)$ & & $\mathrm{LC}_{90}=2.76(2.63-3.14)$ & \\
\hline & $\mathrm{LC}_{10}=0.71(0.31-0.89)$ & & $\mathrm{LC}_{10}=2.11(1.75-2.24)$ & \\
\hline \multirow[t]{2}{*}{$96 \mathrm{~h}$} & $\mathrm{LC}_{50}=0.99(0.71-1.12)$ & $8.77 \pm 2.66$ & $\mathrm{LC}_{50}=2.35(2.19-2.44)$ & $26.72 \pm 7.31$ \\
\hline & $\mathrm{LC}_{90}=1.39(1.24-1.82)$ & & $\mathrm{LC}_{90}=2.63(2.53-2.89)$ & \\
\hline
\end{tabular}

Batches of fifteen fishes were exposed to four different concentrations of the fungicides. Concentrations given are the final concentrations ( $\mathrm{v} / \mathrm{v}$ ) in the aquarium wate containing de-chlorinated tap water. Values given in parenthesis are lower and upper confidence limits of LC value. Negative correlation coefficient is found between the product moment of LC values and exposure periods

Table 1: Pisicidal activity of fungicide propiconazole against different stages of fresh water fish Clarius batracus at different time intervals.

\begin{tabular}{|c|c|c|c|c|c|c|c|c|c|c|}
\hline Con. & Pro & tein & Amin & -acids & Glyc & ogen & & NA & RN & VA \\
\hline & M & L & M & L & M & L & M & L & M & $\mathbf{L}$ \\
\hline Control & $107.14 \pm 0.20(100)$ & $94.20 \pm 0.10(100)$ & $60.33 \pm 0.16(100)$ & $68.22 \pm 0.12(100)$ & $142.34 \pm 0.2(100)$ & $182.20 \pm 0.2(100)$ & $139.35 \pm 0.09(100)$ & $129.21 \pm 0.12(100)$ & $100.45 \pm 0.10(100)$ & $93.20 \pm 0.12(100)$ \\
\hline $\begin{array}{ll}\mathrm{LC}_{50} & 40 \% \\
24 \mathrm{~h}^{*} & \end{array}$ & $91.06 \pm 0.12(85)$ & $75.36 \pm 0.10(80)$ & $71.18 \pm 0.15(118)$ & $78.45 \pm 0.10(115)$ & $111.0 \pm 0.20(78)$ & $118.4 \pm 0.15(65)$ & $107.3 \pm 0.12(77)$ & $96.75 \pm 0.14(75)$ & $76.34 \pm 0.10(76)$ & $68.03 \pm 0.09(73)$ \\
\hline $\begin{array}{ll}\mathrm{LC}_{50} & 80 \% \\
24 \mathrm{~h}^{*} & \end{array}$ & $83.56 \pm 0.10(78)$ & $66.88 \pm 0.15(71)$ & $74.20 \pm 0.16(123)$ & $81.86 \pm 0.20(120)$ & $96.79 \pm 0.13(68)$ & $100.21 \pm 0.10(55)$ & $97.54 \pm 0.08(70)$ & $87.86 \pm 0.17(68)$ & $72.32 \pm 0.07(72)$ & $61.51 \pm 0.08(66)$ \\
\hline $\begin{array}{ll}\mathrm{LC}_{50} & 40 \% \\
72 \mathrm{~h}^{*} & \end{array}$ & $72.85 \pm 0.15(68)$ & $56.52 \pm 0.12(60)$ & $75.41 \pm 0.20(125)$ & $81.86 \pm 0.22(120)$ & $83.98 \pm 0.16(59)$ & $112.96 \pm 0.15(62)$ & $86.39 \pm 0.10(62)$ & $77.52 \pm 0.13(60)$ & $65.29 \pm 0.08(65)$ & $61.51 \pm 0.10(66)$ \\
\hline $\begin{array}{ll}\mathrm{LC}_{50} & 80 \% \\
72 \mathrm{~h}^{*}\end{array}$ & $66.42 \pm 0.13(62)$ & $51.81 \pm 0.14(55)$ & $81.44 \pm 0.229(135)$ & $95.50 \pm 0.15(140)$ & $74.01 \pm 0.10(52)$ & $89.27 \pm 0.18(49)$ & $80.82 \pm 0.07(58)$ & $72.35 \pm 0.10(56)$ & $59.26 \pm 0.12(59)$ & $53.12 \pm 0.13(57)$ \\
\hline
\end{tabular}

Table 2: changes in total protein ( $\mu \mathrm{g} / \mathrm{mg})$, total free amino acids $(\mu \mathrm{g} / \mathrm{mg})$, glycogen $(\mathrm{mg} / \mathrm{g})$, nucleic acids $(\mu \mathrm{g} / \mathrm{mg})$ level and activity of protease (tyrosine/mg protein/h), LDH (pyruvate reduced $/ \mathrm{min} / \mathrm{mg}$ protein), SDH ( $\mu$ moles dye $/ \mathrm{min} / \mathrm{mg}$ protein), GOT ( $\mu$ moles pyruvate/mg protein/h) and GPT ( $\mu \mathrm{moles}$ pyruvate/mg protein/h) in different tissues of fresh water fish clarius batracus exposure to $40 \% \& 80 \%$ of LC $_{50}$ of PCZ at different time intervals. 
Citation: Srivastava P, Singh A (2013) Study of In-Vivo Effects Caused by Metabolites (1,2,4-Trizole Alanine) of Steroid-Inhibitor Fungicide on Aquatic Life (Fish). J Aquac Res Development 4: 183 doi:10.4172/2155-9546.1000183

Page 3 of 5

\begin{tabular}{|c|c|c|c|c|c|c|c|c|c|c|}
\hline \multirow[t]{2}{*}{ Con. } & \multicolumn{2}{|c|}{ Protease } & \multicolumn{2}{|c|}{ LDH } & \multicolumn{2}{|r|}{ SDH } & \multicolumn{2}{|r|}{ GOT } & \multicolumn{2}{|c|}{ GPT } \\
\hline & M & L & $\mathrm{M}$ & L & M & L & M & L & M & L \\
\hline Control & $0.97 \pm 0.011(100)$ & $1.03 \pm 0.015(100)$ & $4.30 \pm 0.16(100)$ & $7.35 \pm 0.12(100)$ & $1.98 \pm 0.02(100)$ & $2.01 \pm 0.05(100)$ & $3.9 \pm 0.09(100)$ & $2.58 \pm 0.07(100)$ & $1.45 \pm 0.01(100)$ & $1.87 \pm 0.06(100)$ \\
\hline $40 \%$ of $\mathrm{LC}_{50} 24 \mathrm{~h}^{*}$ & $1.11 \pm 0.10(115)$ & $1.33 \pm 0.12(130)$ & $4.81 \pm 0.13(112)$ & $8.30 \pm 0.10(113)$ & $1.28 \pm 0.20(65)$ & $1.26 \pm 0.15(63)$ & $4.6 \pm 0.12(120)$ & $3.30 \pm 0.14(128)$ & $1.66 \pm 0.10(115)$ & $2.31 \pm 0.09(124)$ \\
\hline $80 \%$ of $\mathrm{LC}_{50} 24 \mathrm{~h}^{*}$ & $1.16 \pm 0.09(120)$ & $1.40 \pm 0.15(136)$ & $5.07 \pm 0.16(118)$ & $8.82 \pm 0.20(120)$ & $1.18 \pm 0.13(60)$ & $1.14 \pm 0.10(57)$ & $4.9 \pm 0.08(127)$ & $3.61 \pm 0.17(140)$ & $1.74 \pm 0.07(120)$ & $2.39 \pm 0.08(128)$ \\
\hline $40 \%$ of $\mathrm{LC}_{50} 72 \mathrm{~h}^{*}$ & $1.21 \pm 0.11(125)$ & $1.42 \pm 0.10(138)$ & $4.98 \pm 0.20(116)$ & $8.82 \pm 0.22(120)$ & $1.30 \pm 0.16(66)$ & $1.16 \pm 0.15(58)$ & $4.8 \pm 0.10(124)$ & $3.48 \pm 0.13(135)$ & $1.72 \pm 0.08(119)$ & $2.43 \pm 0.10(130)$ \\
\hline $80 \%$ of $\mathrm{LC}_{50} 72 \mathrm{~h}^{*}$ & $1.28 \pm 0.07(132)$ & $1.47 \pm 0.13(143)$ & $5.37 \pm 0.18(125)$ & $9.55 \pm 0.15(130)$ & $1.08 \pm 0.10(55)$ & $1.04 \pm 0.18(52)$ & $5.1 \pm 0.07(133)$ & $3.74 \pm 0.10(145)$ & $1.78 \pm 0.12(123)$ & $2.52 \pm 0.13(135)$ \\
\hline
\end{tabular}

Values given in parenthesis were percent change in parameters, ${ }^{*}(p<0.05)$ significant shows in all parameters

$\mathrm{LDH}=$ Lactic dehydrogenase,

$\mathrm{SHD}=$ Succinic dehydrogenase

GOT=Glutamic oxalic transferase, GPT=Glutamic pyruvate transferase

Table 3: Changes in activity of protease (tyrosine/mg protein/h), LDH (pyruvate reduced/min/mg protein), SDH ( $\mu \mathrm{moles} \mathrm{dye/min/mg} \mathrm{protein),} \mathrm{GOT} \mathrm{(} \mu \mathrm{moles}$ pyruvate/mg protein/h) and GPT ( $\mu$ moles pyruvate/mg protein/h) in different tissues of fresh water fish clarius batracus exposure to $\mathbf{4 0} \% \mathbf{\&} \mathbf{8 0} \%$ of $\mathbf{L C}{ }_{50}$ of PCZ at different time intervals.

liver at $72 \mathrm{~h}$. The transaminase reactivity also shows increase level in muscle and liver. GOT (Glutamic oxalic transaminase) becomes $127 \%$ and $140 \%$ in muscle and liver at $24 \mathrm{~h}$ and $133 \%$ and $145 \%$ in muscles and liver at $72 \mathrm{~h}$. GPT (Glutamic pyruvate transaminase) also increase $120 \%$ in muscles and $128 \%$ in liver at $24 \mathrm{~h}$ and $123 \%$ in muscles and $135 \%$ in liver at $72 \mathrm{~h}$.

\section{Discussion}

In tissues, propiconazole cleaved into propyl side chain and dioxolane ring structure. In liver and muscles tissues it metabolites into 2-4-dichlorophenyl ,1,2,4-trizole alanine ring, trizole acetic acid, trizole pyruvic acid and trizole lactic acid which was the metabolites of the PCZ. In which 1,2,4-trizole alanine is main metabolite of trizole containing fungicides. These metabolites may be conjugates with different metabolic pathways in body of fish and showed maximum effects.

Alanine played most important role in glucose-alanine cycle between tissues and liver. The metabolite 1,2,4-trizole alanine after degradation may be entered into glucose-alanine cycle and induced the collection of amino groups in the form of glutamate by inducing transaminase reaction. This tend to increase in transaminase enzymes such as GOT (Glutamic oxalic transaminase) and GPT (Glutamic pyruvic transaminase) in tissues. In present investigation increase level of GOT and GPT have seen. However, some pesticides caused increased transaminase activity (GPT and GOT) levels in liver and muscle tissues. Begum [20] found the activity levels of GPT and GOT increased in liver and muscle tissues of Clarias batrachus during exposed to carbofuran. Murugesan et al. [21] also found that Sarotherodon mossambicus, when exposed to sublethal and lethal concentrations of carbaryl, showed adaptive elevation in the activity levels of GOT and GPT enzymes, particularly in liver and muscle.

Glutamate can transferred its amino groups to pyruvate by the action of alanine aminotransferase, which leads the glycolysis pathways in liver and muscles tissues. The metabolite 1,2,4-trizole alanine form $\mathrm{N}-(1 \mathrm{H}-1,2,4$ trizole-3-yl)-glucopyranosylamine by the reaction of glucose1-PO and affect the synthesis of oligosaccharides and polysaccharides. Present study showed the reduced value of glycogen in both tissues. Propiconazole treatment altered carbohydrate metabolism with the levels of a number of oligosaccharides reduced in a doseresponse manner such as maltohexaose, maltopentaose, maltotetraose, maltotriose and maltose levels. Increase level of blood glucose concentration caused stress condition in fish respond to acute toxic effects of fungicide. Increase concentration of pesticides considered as reliable indicator of environmental stress [22]. Cicik and Engin [23] observed serum glucose increment in fish under stress condition. In present study, Hyperglycemia indicated disruption in carbohydrate metabolism by elevated breakdown of liver glycogen. Cypermethrininduced hyperglycemia has been recorded in L. rohita [24] and in S. schlegeli [25].Stress is the condition of high energy demanding process and that energy used to cope with stress metabolically [26].The stress hormone cortisol has responsible to increase glucose production by glycolysis pathway in fish [27]. Borges et al. reported that cypermethrininduced hyperglycema in $R$. quelen and associated with the increase in cortisol level in stress condition [28].

Stress condition shows behavior changes in organisms. Fish are ideal indicators for behavioral assays of various stressors and toxic chemicals exposure due to their constant, direct contact with the aquatic environment [29]. Behavior provide a unique perspective linking the physiology and ecology of an organism and its environment [30]. Behavioral action is in a sequence of quantifiable actions that operated through the central and peripheral nervous systems [31] and the cumulative manifestation of genetic, biochemical and physiologic processes essential to life such as feeding, reproduction and predator avoidance. For the best meet of the challenge of surviving in a changing environment, behavior allows an organism to adjust with external and internal stimuli in order to adapted environmental variables. Selective evolutionary processes have conserved stable behavioral patterns in concert with morphologic and physiologic adaptations [30]. Since behavior is not a random process, but instead of it, is a highly structured and predictable sequence of activities designed to ensure maximal fitness and Survival of the individual. Fish are able to uptake and retain different toxicants dissolved in water via active or passive processes. Sub-lethal concentrations of pesticides in aquatic environments cause structural and functional changes in aquatic organisms and this is more common than mortality [32]. Behavioral modification is one of the most sensitive indicators of environmental stress and many affect survival [33]. Alterations in fish behavior, particularly in non-migratory species, can also provide important indices for ecosystem assessment. In the present study, PCZ shows significant behavioral changes in fish (hyperactive movement, hypo movement, vertical position and loss of equilibrium). Toxicity data clearly indicate that the fingerlings are more susceptible than adult fish due to the dependence of age and body size. During stress conditions, the glycogen reserves depleted to meet energy demand $[34,35]$. The freshwater fish, Clarias batracus, has reported to exhibit significant reduction in the level of glycogen Saha et al. studied effects of cypermethrin on various biochemical parameters [36].

PCZ in tissues degrade into different types of amino acids based metabolites so it incorporate with several polypeptide chains and altered its fate. The quantity of protein may also be affected due to impaired incorporation of amino acids in the polypeptide chains [37] 
The protein is the alternative source of energy. Reduction in level of protein in experimental fish under pesticide influence is indicates hepatic insufficiency and probably malnutrition. Protein reduction observes in the present study due to high-energy demand in TCA cycle. The decrease level is also associated with the increase level of protease enzyme in tissues. Decrease in protein content under toxicity stress has already being reported [38]. The decrease in total protein level and increase in free amino acids level in both tissue and liver suggest the high protein hydrolytic activity due to elevation of protease activity [39]. Increase in free amino acids level was the result of breakdown of protein for energy requirements and impaired incorporation of amino acids in protein synthesis and decline in nucleic acids level [40]. In the present study increase, level of amino acids and protease has observed. Prasanth et al. [41] Observed significant elevation in the levels of free amino acids and protease activity in the Indian major carp (Cirrhinus mrigala) in response to cypermethrin. Gregor and John 1995 in serum protein level also observed reduced level.

1H-1,2,4-trizole bearing 4-position of 1,3-dioxolane moiety and an aryloxymethyl group and also nitrogen containing hetero-aromatic ring. Metabolites of trizole produce many $\mathrm{N}_{2}$-containing substances that might be effect on enzymes activity and affect nucleic acids. Reduction in the DNA content is due to impairments of nucleic acids metabolism and the degradation of cells resulting in the tissues. Furthermore, inhibition of DNA synthesis, thus, might affect both protein as well as amino acid levels by decreasing the level of RNA in protein synthesis machinery. The regulatory roles of nucleic acid metabolism as observed in the different animals when treated with the different pesticides [24]. Das and Mukhrejee also reported the reduced level of DNA and SDH activity in brain and liver and increase level of LDH activity in both tissues [24]. Similar results have found in this study. In this study the level of LDH, was significantly increases under the effect of PCZ and depletion occurred in level of SDH and nucleic acids. PCZ has ability to modify the effect of several enzymes. These enzymes are blood soluble enzyme and best indicator of stress conditions [42]. The activity of these two enzymes might be governed by stress hormon cortisol that is the main hormone responsible for stress condition (Iwama et al.) [27]. LDH may indicate changes and hypofunction of liver under the toxicants effects on the hepatocytes are in the form of tissue damage in which cellular enzymes released from the cells into the blood serum. Increase level of LDH shown by the [24]. In the present study, the activity of SDH reduces. It is due to the mitochondrial disruption. SDH activity indicated anoxic hypoxic conditions when the fish exposed to toxicant and it was possibly, leading to decrease in the activities of oxidative enzymes and an increase in the glycolic enzymes reported by Dubale and Awasthi [43]. Reddy et al. reported decreased SDH activity in different tissues of food fish Clarias batrachus exposed to chlorpyrifos [44]. The decrease in SDH activity has reported in the fresh water crab, Spiralothelphusa hydrodroma treated with the pesticides, cypermethrin by Sreenivasan et al. [45].

\section{Conclusion}

Our studied showed that the fungicide (PCZ) which is widely used in vegetable crop fields have potential to damage aquatic fauna. It is highly toxic for fingerlings and adults. It caused severe biochemical and enzymatic alteration in fish. Therefore, we should avoid running off that fungicide in near water bodies.

\section{References}

1. Vanden Bossche H, Marichal P, Gorrens J (1989) Biochemical approaches to selective antifungal activity. Focus on azole antifungals. Journal of Mycoses 32: $35-52$.
2. Warmerdam MA (2008) California Department of Pesticide Regulation Summary of Pesticide Use Report Data 2008 Indexed by Chemical: 547

3. Allen JW, Wolf DC, George MH, Hester SD, Sun G, et al. (2006) Toxicity profiles in mice treated with hepatotumorigenic and non-hepatotumorigenic triazole conazole fungicides: propiconazole, triadimefon, and myclobutanil. Toxico Pathol 34: 853-862.

4. Chen PJ, Padgett WT, Moore T, Winnik W, Lambert GR, et al. (2009) Three conazoles increase hepatic microsomal retinoic acid metabolism and decrease mouse hepatic retinoic acid levels in vivo. Toxicol Appl Pharmacol 234: 143155

5. Dewhurst I, Dellarco V (2004) In International Programme on Chemical Safety Evaluations 2004, Part 2 Propiconazole.

6. Konwick BJ, Garrison AW, Avant JK, Fisk AT (2006) Bioaccumulation and biotransformation of chiral trizole fungicides in rainbow trout (Oncorhynchus mykiss). Aquatic Toxicology 80: 372-38.

7. Chen PJ, Moore T, Ne snow S (2008) Cytotoxic effects of propiconazole and its metabolites in mouse and hepatoma cells and primary mouse hepatocytes. Toxicol In Vitro. 22: 1476-1483.

8. Bruno M, Moore T, Nesnow S, Ge Y (2009) Protein carbonyl formation in response to propiconazole-induced oxidative stress. J Proteome Res 8: 2070 2078

9. Nesnow S, Ward W, Moore T, Ren H, Hester SD (2009) Discrimination of tumorigenic triazole conazoles from phenobarbital by transcriptional analyses of mouse liver gene expression. Toxicol Sci 110: 68-83.

10. Singh A, Agarwal RA (1988) Possibility of using latex of euphorbiales for snail control. Science and Toxicol Environ 77: 231-368.

11. Sokal RR, Rohlf FJ (1973) Introduction of biostatistics WH Freeman and Comp San Francisco.

12. Lowry OM, Rosebrough NJ, Ferr AC, Randall RF (1951) Protein estimation with Folin Phenol reagent. Journal of Biology and Chemistry 193: 265-275.

13. Spice JR (1957) Calorimetric products for amino acids, Method in enzymology. (Eds) Academic Press. 468

14. Schneider W C (1957) Determination of nucleic acids in tissue by pentose analysis. Academic Press New York 680.

15. Van der Vies $\mathrm{J}$ (1954) Two methods for the determination of glycogen in liver. Biochemical J 57: 410-416.

16. Anon (1984) Sigma diagnostics TM Lactic dehydrogenase (quantitative colorimetric determination in serum, urine and cerebrospinal fluid) at 400-450 nm. Prrocedure No. 500 Sigma chemical company, St. Louis, USA.

17. Arrigon O, Singer T (1962) Limitations of the phenazine methosulphate assay for succinic and related dehydrogenase. Nature 193: 1256-1258.

18. Moore S, Stein WH (1954) A modified Ninhydrin reagent for the photometric determination of aminoacids and related compounds. J Biol Chem 221: $907-$ 913

19. Reitman S, Frankel S (1957) A colorimetric method for the determination of serum glutamic oxaloacetic and glutamic-pyruvic transaminases. Am J Clin Pathol 28: 56-63.

20. Begum G (2004) Carbofuran insecticide induced biochemical alterations in live and muscle tissues of the fish Clarias batrachus (Linn) and recovery response. Aquat Toxicol 66: 83-92.

21. Murugesan R, Palaniswamy TN, Panneer S (1999) Glutamic oxaloacetic transaminase (GOT) and glutamic pyruvic transaminase (GPT) enzyme activities in different tissues of Sarotherodon mossambicus (Peters) exposed to a carbamate pesticides, carbaryl. Pesticide Science 55: 1217-1221.

22. Sepici-Dinçel A, Benli ACK, Selvi M, Sarıkaya R, Şahin D, et al. (2009) Sublethal cyfluthrin toxicity to carp (Cyprinus carpio L.) fingerlings: biochemical hematological, histopathological alterations. Ecotoxicol Environ Saf 72:1433 1439

23. Cicik B, Engin K (2005) The effects of cadmium on levels of glucose in serum and glycogen reserves in the liver and muscle tissues of Cyprinus carpio. Turk J Vet Ani Sci 29: 113-117.

24. Das BK, Mukherjee SC (2003) Toxicity of Cypermethrin in Labeo rohita 
Citation: Srivastava P, Singh A (2013) Study of In-Vivo Effects Caused by Metabolites (1,2,4-Trizole Alanine) of Steroid-Inhibitor Fungicide on Aquatic Life (Fish). J Aquac Res Development 4: 183 doi:10.4172/2155-9546.1000183

fingerlings: biochemical, enzymatical and haematological consequences. Comp Biochem Physiol C Toxicol Pharmacol 134: 109-121.

25. Jee J-H, Masroor F, Kang JC (2005) Responses of cypermethrin-induced stress in haematological parameters of Korean rockfish, Sebastes schlegeli (Hilgendorf). Aquatic Research 36: 898-905.

26. Vijayan MM, Cristina Pereira E, Grau G, Iwama Gk (1997) Metabolic responses associated with confinement stress in tilapia: the role of cortisol. Comparative Biochemistry and Physiology 116C: 89-95.

27. Iwama GK, Vijayan MM, Forsyth RB, Ackerman PA (1999) Heat shock proteins and physiological in fish. Amer Zool 39: 901-909.

28. Borges A, Scotti LV, Siqueira DR (2007) Changes in hematological and serum biochemical values in jundiá Rhamdia quelen due to sub-lethal toxicity of cypermethrin. Chemosphere 69: 920-926.

29. Little EE, Fairchild JF, DeLonay AJ (1993) Behavioural methods for assessing the impacts of contaminants on early life stage fishes. Water Quality and the Early Life Stages of Fishes. In proceedings of 14th Americn Fish Society Symposium Bethesda, Maryland 67-76.

30. Little E, Brewer SK (2001) Neurobehavioural toxicity in fish. Target Organ Toxicity in Marine and Freshwater Teleosts New Perspectives. In: Toxicology and the Environment Taylor and Francis London and New York 2: 139-174.

31. Keenleyside MHA (1979) Diversity and adaptation in fish behavior. Zoology physiology 11: 208

32. Sancho E, Fernandez-Vega C, Ferrando MD, Andreu-Moliner E (2003) Eel ATPase activity as biomarker of thiobencarb exposure. Ecotoxicol Environ Saf 56: 434-441

33. Byrne PA, O'Halloran J (2001) The role of bivalve molluscs as tools in estuarine sediment toxicity testing: A review. Hydrobiologia 465: 209-217.

34. Rawat DK, Bais VS, Agrawal NC (2002) A correlative study on liver glycogen and endosulfan toxicity in Heteropneustes fossils. J Environ Biol 23: 205-207.

35. Tiwari S, Singh A (2009) Changes in some biochemical parameters in the liver and muscle of Colisa fasciatus due to toxicity of ethanolic extract of Nerium indicum Mill(Lal Kaner) latex. Natural Product Radiance 8: 48-54.
36. Saha S, Kaviraj A (2009) Effects of cypermethrin on some biochemical parameters and its amelioration through dietary supplementation of ascorbic acid in freshwater cat fish Heteropneustes fossilis . Chemospher 74: 12541259.

37. Singh A, Singh DK, Agrawal RA (1996) Molluscicides of plant origin. Biological Agriculture and Horticulture 13: 205-252.

38. Khare A, Singh S (2002) Impact of Malathion on protein content in the freshwater fish Clarias batrachus. Journal of Ecotoxicology and Environmenta Monitoring. 12: 129-132.

39. Muley DV, Karanjkar DM, Maske SV (2007) Impact of industrial effluents on the biochemical composition of freshwater fish Labeo rohita. J Environ Bio 28: $245-249$.

40. Bhavan PS, Geraldine P (2001) Biochemical stess responses in tissues of the prawn Macrobrachium malcolmsonii on exposure to endosulphan. Journal of Pesticide Biochemistry Physiology 70: 27-41.

41. Prasanth MS, David M, Mathed SG ( 2006) Behavioural changes in freshwater fish Ctenopharyngodon IDELLUS (Hamilton) exposed to cypermethrin. Journal of Ecotoxicology and Environmental Monitoring. 26: 141-144.

42. Palanivelu V, Vijayavel K, Ezhilarasibalasubramanian S, Balasubramanian MP (2005) Influence of insecticidal derivative (Cartap Hydrochloride) from the marine polychaete on certain enzyme systems of the freshwater fish Oreochromis mossambicus. J Environ Biol 26: 191-195.

43. Dubale MS, Awasthi M (1982) Biochemical changes in the liver and kidney of a catfish, heteropneustes fossilis exposed to dimethoate. Comparative Physiology \& Ecology 7: 111-114.

44. Reddy NM, Ghousia B, Rajender K, Rao JV (2011a) Toxic impact of two Organophosphate insecticides on biochemical parameters of a food fish and assessment of recovery response. Toxicol Ind Health 28: 343-352.

45. Sreenivasan RS, Krishna Moorthy P, Deecaraman M (2011) Cypermethrin Induced Toxicity to phosphatases and dehydrogenases in gills and hemolymph of fresh water crab, Spiralothelphusa hydrodroma(Herbst). International Journal of Biology \& Medical Research 2: 616-620. 